\title{
Foucault's analysis of subjectivity and the question of philosophizing with words or things
}

\section{Senem Öner ${ }^{1}$}

\begin{abstract}
This article examines how Foucault analyzes subjectivity within the frame of his approach concerning power and discourse, and the concepts of archaeology and problematization as all discursive and non-discursive practices that constitute the subject and subjective experience. The article investigates the philosophical and political implications occurring as a result of Foucault's rejection of the idea of natural, ahistorical, founding and constituting subject at the outset and his emphasis on the history of the constitution of subjectivity, i. e. the very historicity and historical singularity of subjective experience. Pursuing an answer to the question whether Foucault philosophizes with words or things, the present study claims that Foucault does not philosophize either by words or things in Durkheimian sense but does so by analyzing discourse as practices forming the object of which they speak systematically.
\end{abstract}

Keywords: Foucault; subjectivity; power; discourse; problematization

\section{Introduction}

In "The Subject and Power", Foucault defines "the general theme of his research" as "subject" However, how Foucault deals with this theme is an unprecedented one in terms of both the way it deals with it and the underlying aim of his research. First of all what Foucault tries to do is not to find what subject and subjectivity is but rather to find how subjectivity and identity is historically constituted. In his words, his objective "is to create a history of the different modes by which...human beings are made subjects" ${ }^{3}$. In The Use of Pleasure, he tells that "it (the book) was intended to be neither a history of sexual behaviors nor a history of representations, but a history of sexuality".

According to Foucault, identity is dangerous because of the constraints it imposes. In his view, identity and individuality consist of set of experiences and they become our subjective experiences when we see them as our behaviors. As one of the basic premises of his analysis of subjectivity, Foucault rejects the idea of natural, ahistorical, founding, and constituting subject at the outset: what is essential is the history of the constitution of subjectivity and subjective experience, i. e. the

\footnotetext{
${ }^{1}$ Assist. Prof. Dr., İstanbul Arel University, Faculty of Science and Letters, Department of Translation and Interpreting, senemoner@arel.edu.tr

2Foucault, M. (2000), The Subject and Power. Power: Essential Works of Foucault, 1954-1984, Vol. 3, (ed.) J. D. Faubion, New York: The New Press, p.327.

3 ibid., p.326.

${ }^{4}$ Foucault, M. (1986). The Use of Pleasure: History of Sexuality, Vol. 2, New York: Vintage, p.3.
} 
Öner, S. (2016). Foucault's analysis of subjectivity and the question of philosophizing with words or things. International Journal of Human Sciences, 13(1), 479-486. doi: 10.14687/ijhs.v13i1.3493

very historicity and historical singularity of subjective experience, which has highly important philosophical and political consequences.

Foucault's preoccupation with the theme of subject has a basic and highly important motive, which renders his research a political one. Foucault suggests that "may be the target nowadays is not to discover what we are, but to refuse what we are. We have to imagine and to build up what we could be to get rid of this kind of political "double bind", which is the simultaneous individualization and totalization of modern power structures"

With the ultimate aim of trying to find "new forms of subjectivity and to be liberated from the state

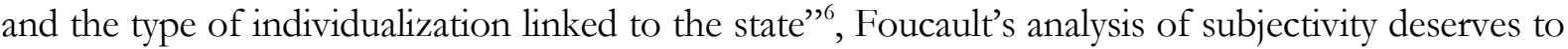
be considered carefully in terms of both its groundbreaking effect on philosophizing tradition in the west and its strongly political aim with regard to resistance and the search for new alternatives. Because, once we start to think that our subjective experiences and identities are constituted, we can become more hopeful about resisting what is imposed on us and about creating new, alternative forms of subjectivity.

Before trying to dwell upon Foucault's analysis of subjectivity and identity, there are two important preliminary points to be considered, I guess, which may help to clarify Foucault's disciplinary stance and his position in terms of doing social science or research. One of these is Foucault's rejection of theory and the other is his ideas about three most influential social science disciplines: phenomenology, philosophical anthropology and social history.

While talking about the study of power, Foucault asks: "[D]o we need a theory of power?" and then he argues "since a theory assumes a prior objectification, it cannot be asserted as a basis for analytical work" ". Instead of theory, Foucault proposes analysis. Although one may think that an analysis also assumes objectification, Foucault's preference of analysis is much more related with the question to be asked, I suppose. Because rather than "what" and "why", Foucault asks "how", he begins analysis with "how", and this is the point where his idea of analysis differs from theory. Because, according to Foucault, "to begin the analysis with a "how" is to introduce the suspicion that power as such does not exist". Also in "Questions of Method", Foucault explains his reasoning as follows: " $\Pi$ n order to get a better understanding of what is punished and why, I wanted ask the question: how does one punish? This was the same procedure as I had used when dealing with madness: rather than asking what, in a given period, is regarded as sanity or insanity, as mental illness or normal behavior, I wanted to ask how these divisions are operated"?. What Foucault thinks of analysis and analysis of power is quite significant in terms of understanding his analysis of subjectivity, since he, rather than inquiring "what is subject", asks "how subjectivity is constituted".

Foucault's stance toward the above-mentioned three approaches or disciplines is also closely related with the analysis of subjectivity. According to Ferda Keskin, the reason that Foucault rejects phenomenological approach is grounded on that he rejects the approaches that focus on subject and tries to find how subject lives experience in order to explain the source of subjective experience and how it is formed ${ }^{10}$. The problem Foucault observes in philosophical anthropology is again closely related with subject and grounded on Foucault's rejection of a "universal" and "essential" human nature. Considering the interrelation of Foucault's ideas about phenomenology and

\footnotetext{
5 ibid., p. 336.

6 ibid., p.336.

7 ibid., p.327.

8 ibid., p. 336.

${ }^{9}$ Foucault, M. (1986) Questions of Method: An Interview with Michel Foucault. After Philosophy: End or Transformation?, (eds.) K. Baynes, J. Bohman and T. McCarthy, Cambridge, MA: MIT Press.

${ }^{10}$ Keskin, F. (2000). Özne ve İktidar. Özne ve İktidar. Michel Foucault. Sę̧me Yą̧lar 2, (ed.) F. Keskin, (trans.) I. Ergüden and O. Akınhay, İstanbul: Ayrıntı, p. 12.
} 
Öner, S. (2016). Foucault's analysis of subjectivity and the question of philosophizing with words or things. International Journal of Human Sciences, 13(1), 479-486. doi: $\underline{10.14687 / \text { ijhs.v13i1.3493 }}$

philosophical anthropology, Keskin states that "Foucault's approach towards phenomenology is complementary with a more basic philosophical choice", i. e. "Foucault's reaction to all theoretical approaches which explain why subject lives experience in this or that way by referring to human nature, which, in short are based on philosophical anthropology, which is anthropologism in Foucault's words"11.

According to Maurice Florence, in Foucault's analysis of the relations between subject and power, first of the methodological choices is a "systematic skepticism with regard to all anthropological universals" of existential analysis but left unsatisfied for two reasons, one of which is "its theoretical weakness in elaborating notion of experience and the other is its ambiguous link with a psychiatric practice"13. In his view, if one chooses to "deal with the first problem by referring to a general theory of the human being, and treat the second altogether differently by turning to the economic and social context, one could choose by doing so, to accept the resulting dilemma of a philosophical anthropology and a social history"14.

What Foucault proposes rather than philosophical anthropology and social history is one of the key points of his analysis of subjectivity: "But I wondered, rather than playing on this alternative, it would not be possible to consider the very historicity of forms of experience"15.

One of the most crucial aspects of Foucault's analysis of subjectivity and identity is his concept of historical a priori. Historical a priori is all the discursive and non-discursive rules that provide the formation of knowledge that constitutes our subjective experience. In The Archaeology of Knowledge, for the term historical a priori Foucault says: "juxtaposed these two words produce a rather startling effect......but what I mean by the term is an a priori that is not a condition of validity for judgments, but a condition of reality for statements" ". Foucault also mentions that "this a priori does not elude historicity: it does not constitute, above events, and in an unmoving heaven, an atemporal structure, it is defined as the group of rules that characterize a discursive practice"17.

As it is explicit, Foucault's concept of a priori is quite different from Kant's a priori. Because, while Kant's a priori is transcendental, universal and ahistorical, Foucault's a priori is historical. And by creating the history of historical a priori, Foucault creates the history of how we are forced to think in certain ways.

\section{Problematization}

As mentioned before, Foucault rejects the idea of founding and transcendental subject. According to him, subject is historically constituted, and what is to be analyzed is how this constitution occurs. Problematization is the first key concept I would like to dwell upon, because in Foucault's thought, "how subjectivity is constituted" can also be expressed as "how subjectivity is problematized", too. In The Use of Pleasure, Foucault defines his work as "a matter of analyzing, not behaviors or ideas, nor societies and their "ideologies", but the problematizations through which being offers itself to be, necessarily, thought-and the practices on the basis of which these problematizations are formed"18.

\footnotetext{
11 ibid., p. 12.

${ }^{12}$ Florence, M. (1994). Foucault, Michel, 1926-. The Cambridge Companion to Foucault, (ed.) G. Gutting, Cambridge: Cambridge University Press, p. 317.

${ }^{13}$ Foucault, M. (1994). Preface to the History of Sexuality. Ethics: Subjectivity and Truth, Essential Works of Foucault, Vol. 1, (ed.) P. Rabinow, New York: The New Press, p. 200.

14 ibid, p. 200.

15 ibid., p. 200.

${ }^{16}$ Foucault, M. (1997) The Archaeology of Knowledge, London: Routledge, p. 127.

17 ibid., p. 137.

${ }^{18}$ Foucault, M. (1986). The Use of Pleasure: History of Sexuality, Vol. 2, New York: Vintage, p. 11.
} 
Öner, S. (2016). Foucault's analysis of subjectivity and the question of philosophizing with words or things. International Journal of Human Sciences, 13(1), 479-486. doi: $\underline{10.14687 / \text { ijhs.v13i1.3493 }}$

Problematization is also a key concept because "it is the common notion which informed all the researches (of Foucault) since Madness and Civilization",

Problematization is "a totality of discursive and non-discursive practices which makes something enter the game of truth and which constitutes it as an object of thought" ${ }^{20}$. According to Ferda Keskin, "Foucault interprets his own works as a history of the problematization processes that constituted experiences such as madness, illness, life, language, labor, crime and sexuality, which, Foucault thinks, have a special place in the subjectification of human beings in Western culture"21.

So, problematization is all discursive and non-discursive practices that constitute the subject and subjective experience. However there is something critical to be mentioned concerning problematization. Arguing that problematization constitutes subjective experience does not mean that the ways of thinking, feeling and acting that these experiences refer do not exist. For instance, in the case of madness, as Keskin mentions, "the aim of analysis is not to prove that there was not anything as madness before problematization, but to see if with which discourses, games of truth and definitions the madness was problematized and by this way included into an institutional space which would cause it to be named as "mental illness". So, when madness is problematized through certain discursive and non-discursive practices, it becomes or named as "mental illness".

Problematization occurs through three main axes, which are knowledge, power and ethics ${ }^{22}$. Subjective experience is constituted by three interrelated spaces, one of which is the sphere of knowledge which has certain concepts and theories and which produce certain truths; the other is the sphere of power which has certain norms and rules; and the third is a sphere of ethic, which is the form of relationship of individual with herself ${ }^{23}$. So, in his analysis Foucault asks, "how are we constituted as the subject of knowledge, subject of power of relations and the ethic subject of our actions" ${ }^{\prime 24}$.

\section{Power}

Of these axes, which are equally elaborated in Foucault's thought, the second axe seems to be the most outstanding one, to such an extent that Foucault feels to emphasize that "the general theme of his research is not power, but subject". What renders power so central in terms of Foucault's analysis of subjectivity is that the very reason Foucault analyzes power is the question of subject ${ }^{25}$. Foucault emphasize that the general theme of his research is not power but subject, but he was so much involved with power because, again in his own words, "it soon appeared to me (Foucault) that, while the human subject is placed in relations of production and of signification, he is equally placed in power relations that are very complex"26.

Foucault's analysis or perhaps idea of power is also as groundbreaking as his analysis of subject and subjectivity. First of all, according to Foucault, there is not Power with capital P, but power relations, and as Keskin mentions, "it is a form of relation, an action...it is a total structure in which

\footnotetext{
${ }_{19}$ Foucault, M. (2000). Hakikat Kaygısı. Özne ve Iketidar. Michel Foucault. Seçme Yaz̨lar 2, (ed.) F. Keskin, (trans.) I. Ergüden and O. Akınhay, İstanbul: Ayrınt1, p. 85.

20 ibid., p.86.

21 ibid., 13.

${ }^{22}$ Keskin, F. (2000). Özne ve İktidar. Özne ve İktidar. Michel Foucault. Seçme Yą̧lar 2, (ed.) F. Keskin, (trans.) I. Ergüden and O. Akınhay, İstanbul: Ayrınt, p. 14.

23 ibid., p.14.

24 ibid., p.14.

${ }^{25}$ Foucault, M. (2000), The Subject and Power. Power: Essential Works of Foucault, 1954-1984, Vol. 3, (ed.) J. D. Faubion, New York: The New Press, p.326.

26 ibid., p. 327.
} 
Öner, S. (2016). Foucault's analysis of subjectivity and the question of philosophizing with words or things. International Journal of Human Sciences, 13(1), 479-486. doi: 10.14687/ijhs.v13i1.3493

one set of actions have an effect on other set of actions" ${ }^{27}$. This view is also significant in terms of its political implications, because getting rid of the idea of Power as an all-encompassing, monolithic entity and beginning to consider it as a relation would open new ways of resisting which may have chance to not to reproduce the imposed subjectivities and identities, and which may open new ways of resisting this imposition.

Before passing to the second aspect of Foucault's analysis of power, one important thing to be mentioned is his idea of rationality and its relation to power. According to Foucault, "the relation between rationalization and excesses of political power is evident" 28 . Foucault rejects to turn to reason in order to investigate this evident fact, i.e. the links between rationalization and power on the ground that "nothing would be more sterile". According to him, the reasons for this are "first, because the field has nothing to do with guilt or innocence. Second, because it is senseless to refer to reason as the contrary entity to nonreason. Lastly, because such a trial would trap us into playing the arbitrary and boring part of either the rationalist or the irrationalist" ${ }^{\prime 29}$.

In the same way as he rejects a transcendental subject or Power as an exterior, substantial entity, Foucault rejects an exterior, substantial rationality. In his view, rationality is a totality of rules, and he argues that the word "rationalization" is dangerous. According to him, what we have to do is "to analyze specific rationalities rather than always invoking the progress of rationalization in general". And he proposes "to analyze such a process in several fields, each with reference to a fundamental experience: madness, illness, death, crime, sexuality and so forth" ${ }^{30}$.

The second striking aspect of Foucault's analysis of power is related to the change or transformation of power in the context of development of capitalism. According to Foucault, beginning with the end of the seventeenth century, with the development of capitalism and bourgeois society, the juridico-discursive model of power, which is negative, constraining, depending on law, punishment and obedience was replaced by a positive and productive one, which aims at supporting life and the forces of life. Foucault calls this as bio-power and argues that this power interferes life in two ways, first in a disciplinary way which aims at rendering the human body more docile and productive, which Foucault calls the "anatomo-politics of body"; and second in a regulatory way which aims at regulating the population and rendering it suitable for the process of production which Foucault calls the "bio-politics of population". 31

Foucault's analysis of power has very significant implications for identity and subjectivity. Because, according to Foucault, this form of power demonstrates that the human life has entered the sphere of history and the political techniques ${ }^{32}$, and as Keskin mentions "subjectivity, personality and consciousness are the consequences of the discourse of the power which it developed in order to besiege the human body ${ }^{33}$. And precisely here is the point Foucault rejects the imposed subjectivities and identities. Because, "this form of power that applies itself to immediate everyday life categorizes the individual, marks him by his own individuality, attaches him to his own identity, imposes a law of truth on him that he must recognize and others have to recognize in him. It is a form of power that makes individuals subjects. There are two meanings of the word "subject": subject to someone else by

\footnotetext{
${ }^{27}$ Keskin, F. (2000). Özne ve İktidar. Özne ve İktidar. Michel Foucault. Sę̧me Yą̧lar 2, (ed.) F. Keskin, (trans.) I. Ergüden and O. Akınhay, İstanbul: Ayrınt, p. 20.

${ }^{28}$ Foucault, M. (2000), The Subject and Power. Power: Essential Works of Foucault, 1954-1984, Vol. 3, (ed.) J. D. Faubion, New York: The New Press, p.328.

29 ibid., p. 328.

30 ibid., p.329.

31 ibid., p.16, 17.

32 ibid., p.17.

33 ibid., p. 19
} 
Öner, S. (2016). Foucault's analysis of subjectivity and the question of philosophizing with words or things. International Journal of Human Sciences, 13(1), 479-486. doi: 10.14687/ijhs.v13i1.3493

control and dependence, and tied to his own identity by a conscience or self-knowledge. Both meanings suggest a form of power that subjugates and makes subject to" ${ }^{34}$.

\section{Archaeology}

As the method Foucault uses to analyze discursive practices, archaeology is another key point in Foucault's thought. In The Archaeology of Knowledge, Foucault defines archaeology as "the systematic description of the discourse-object" 35 . In his account of archaeology, Foucault firstly emphasizes the difference of archaeology from the "history of ideas". According to him, "history of ideas" is the discipline of beginnings and ends, the description of obscure continuities and returns, the reconstitution of developments in their linear form of history" ${ }^{36}$, while "archeological description is precisely such an abandonment of the history of ideas, a systematic rejection of its postulates and procedures, an attempt to practice a quite different history of what men have said"37. As Foucault puts it, archaeology "tries to define not the thoughts, representations, images, themes, preoccupations that are concealed or revealed in discourses, but those discourses themselves, those discourses as practices obeying certain rules...its problem is to define discourses in their specifity" ${ }^{38}$.

To understand Foucault's analysis of subjectivity better, one has also consider the two set of rules Foucault gives in The Archaeology of Knowledge: The rules for the formation of objects and the rules for the formation of enunciative modalities. The first rule for the formation of objects is the rules regulating the surfaces of emergence, which concern the social places from which the objects of a discursive formation emerge such as family, immediate social group and religious community. The second rule is the ones regulating the authorities of delimitation, and the third are the rules regulating grids of specification, for example "the systems according to which the different "kind of madness" are divided, contracted, related, regrouped, classified, derived from one another as objects of psychiatric discourse" 39 .

Rules for the formation of enunciative modalities are especially important and clarifying for Foucault's analysis of subjectivity. The first rule concerns the following questions: "Who is speaking?"; "Who, among the totality of speaking individuals, is accorded the right to use this sort of language?", "Who is qualified to do so?" 40 The second rule concerns the institutional site, for example a site "from which the doctor makes his discourse, and from which this discourse derives its legitimate source and point of application" ${ }^{41}$. And the last concerns the position of subject; such as speaking subject, questioning subject, listening subject and so on. These two set of rules, besides being crucial in terms of understanding Foucault's analysis of subject, are highly explanatory in terms of his idea of discourse, which is another cornerstone of Foucault's thought.

\section{Discourse}

As it is obvious in the definition of archaeology, discourse is another crucial concept in Foucault's analysis. But what does Foucault mean by the term "discourse"? Is it a linguistic term, or does

\footnotetext{
${ }^{34}$ Foucault, M. (2000), The Subject and Power. Power: Essential Works of Foucault, 1954-1984, Vol. 3, (ed.) J. D. Faubion, New York: The New Press, p.331 (emphasis mine).

35 Foucault, M. (1997). The Archaeology of Knowledge, London: Routledge, p. 140.

36 ibid., p. 137.

37 ibid., p. 138.

38 ibid., p. 139, 140.

${ }^{39}$ Foucault, M. (1997). The Archaeology of Knowledge, London: Routledge, p. 42.

40 ibid., p.50.

41 ibid., p. 51
} 
Öner, S. (2016). Foucault's analysis of subjectivity and the question of philosophizing with words or things. International Journal of Human Sciences, 13(1), 479-486. doi: 10.14687/ijhs.v13i1.3493

Foucault use it in a different way? In The Formation of Enunciative Modalities, while talking about the discourse of nineteenth-century doctors, what Foucault includes in the discourse of doctors is quite explanatory in terms of what he means by "discourse": "Qualitative descriptions, biographical accounts, the location, interpretation and cross-checking of signs, reasonings by analogy, deduction, statistical calculations, experimental verifications and many other forms of statement are to be found in the discourse of nineteenth-century doctors" ${ }^{\prime 2}$. Another example to clarify what Foucault means by discourse or discursive formations and how these are different from non-discursive formations is perhaps the one Veli Urhan mentions: Foucault, in Surveillance and Punish, calls prisons "non-discursive formations", while calling penal law "discursive formations" 43 . Discourse is of utmost importance with regard to Foucault's analysis of identity and subjectivity, because together with the non-discursive practices it makes human beings subjects. However, although it is closely related with language, it is not a mere linguistic formation, but a "much more complex reality"

\title{
Words or things, or neither words nor things?
}

\author{
"The first and most fundamental rule is: Consider social facts as things."45
}

\section{-Durkheim}

Discourse is quite an appropriate point to discuss the question of philosophizing with words or things, I guess. First of all, what does philosophizing with things mean must be made clear, which is the way Durkheim philosophizes. In The Rules of Sociological Method, Durkheim defines social fact as "every way of acting which is general throughout a given society, while at the same time existing in its own right independent of its individual manifestations" $"$. He then argues that social facts should be considered as things. According to Durkheim, when an analysis focuses on ideas, when a science proceeds from ideas to things, the result is no more than an ideological analysis. However, in his view, analysis should focus on realities, science should proceed from things to ideas, because the other way cannot give objective results and those ideas or concepts are not legitimate substitutes for things. ${ }^{47}$ And again according to Durkheim, up to his time, sociology has dealt more or less exclusively with concepts and not with things.

Durkheim's concern about "things" is related with his concern about an objective sociology, and it is clear that he is in favor of philosophizing with things. However, considering his analysis of subject and subjectivity as I tried to explain above, it is also clear that Foucault does not philosophize with things in Durkheimian sense. Because, in his analysis of subjectivity, Foucault rejects the question of "what" and starts with "how"; because he rejects the idea of a constituting subject and tries to find how it is constituted; because he rejects the idea of an external, allencompassing Power and tries to search for power relations; and because he argues that with nondiscursive practices, discursive practices constitutes the subject through problematization. So, it is clear that he does not philosophize with things. Is he then, philosophizes with words? This question is much more difficult to answer.

In "The Formation of Enunciative Modalities", Foucault emphasizes that "discourse is not the majestically unfolding manifestation of thinking, knowing, speaking subject, but, on the contrary, a totality, in which the dispersion of the subject and his discontinuity with himself may be determined" and that he "showed earlier that it was neither by "words" nor by "things" that the

\footnotetext{
42 ibid., p. 50.

${ }^{43}$ Urhan, V. (2000). Michel Foucault ve Arkeolojik Cözümleme, İstanbul: Paradigma, p. 15.

44 ibid., p. 20.

${ }^{45}$ Durkheim, E. (1958). The Rules of Sociological Method, Glencoe, Illinois: The Free Press, p.14.

46 ibid., p. 13, (emphasis mine).

47 ibid., p. 15.
} 
Öner, S. (2016). Foucault's analysis of subjectivity and the question of philosophizing with words or things. International Journal of Human Sciences, 13(1), 479-486. doi: 10.14687/ijhs.v13i1.3493

regulation of the objects proper to a discursive formation should be defined, similarly, it must now be recognized that it is neither by recourse to a transcendental subject nor by recourse to a psychological subjectivity that the regulation of its enunciations should be defined" ${ }^{\text {"48 }}$. Similarly, in "Formation of Concepts", he insists that "in order to analyse the rules for the formation of objects, one must neither embody them in things, nor relate them to the domain of words" ${ }^{\prime 4}$.

To return to the question whether Foucault philosophizes with words or things, it seems that he does not philosophize either by words or by things in Durkheimian sense. However, "what is said" is of utmost importance for Foucault's analysis, yet it is not enough. Because, as it is explicit in his analysis of identity and subjectivity, and in his definition of problematization which is a totality of discursive and non-discursive practices, Foucault, besides "what is said", analyses "what is done", i. e. practices. But these are not "things", i. e. these are not external, independent entities or facts in Durkheimian sense. So, it can be said that Foucault philosophizes with words, however what is decisive is how "words" are defined. Yes, rather than things, Foucault philosophizes with "words", but not in a linguistic sense. What he defends is not something like linguistic idealism which argues that the objects are constituted by language. And what he analyses is more than signs, as he himself very clearly states: "Words and things' is the entirely serious title of a problem; it is the ironic title of a work that modifies its own form, displaces its own data, and reveals, at the end of the day, a quite different task. A task that consists of not - of no longer - treating discourses as groups of signs...but as practices that systematically form the object of which they speak. Of course, discourses are composed of signs; but what they do is more than use this signs to designate things. It is this more that renders them irreducible to the language (langue) and to speech. It is this "more" that we must reveal and describe"

\section{References}

Durkheim, E. (1958). The Rules of Sociological Method, Glencoe, Illinois: The Free Press.

Florence, M. (1994). Foucault, Michel, 1926-. The Cambridge Companion to Foucault, (ed.) G. Gutting, Cambridge: Cambridge University Press.

Foucault, M. (2000). Hakikat Kayg1sı. Özne ve İktidar. Michel Foucault. Seçme Yą̧lar 2, (ed.) F. Keskin, (trans.) I. Ergüden and O. Akınhay, İstanbul: Ayrıntı.

(2000), The Subject and Power. Power: Essential Works of Foucault, 1954-1984, Vol. 3, (ed.) J. D. Faubion, New York: The New Press.

(1997). The Archaeology of Knowledge, London: Routledge.

- (1994). Preface to the History of Sexuality. Ethics: Subjectivity and Truth, Essential Works of Foucault, Vol. 1, (ed.) P. Rabinow, New York: The New Press, p. 200.

(1986) Questions of Method: An Interview with Michel Foucault. After Pbilosophy: End or Transformation?, (eds.) K. Baynes, J. Bohman and T. McCarthy, Cambridge, MA: MIT Press.

(1986). The Use of Pleasure: History of Sexuality, Vol. 2, New York: Vintage.

Keskin, F. (2000). Özne ve İktidar. Özne ve İktidar. Michel Foucault. Seçe Yaz̨lar 2, (ed.) F. Keskin, (trans.) I. Ergüden and O. Akınhay, İstanbul: Ayrıntı.

Urhan, V. (2000). Michel Foucault ve Arkeolojik Çörümleme, İstanbul: Paradigma.

\footnotetext{
${ }^{48}$ Foucault, M. (1997). The Archaeology of Knowledge, London: Routledge, p. 55.

${ }^{49}$ ibid., p.63

50 ibid., p. 49
} 